\title{
PHYTOPLANKTON NYCTEMERAL VARIATION AT A TROPICAL RIVER ESTUARY (ITAMARACÁ - PERNAMBUCO - BRAZIL)
}

\author{
LACERDA, S. R., ${ }^{1,2}$ KOENING, M. L., ${ }^{2}$ NEUMANN-LEITÃO, S. ${ }^{2}$ and \\ FLORES-MONTES, M. J.2 \\ ${ }^{1}$ Universidade Regional do Cariri, URCA, Ceará, Brazil \\ ${ }^{2}$ Departamento de Oceanografia da Universidade Federal de Pernambuco, Brazil \\ Correspondence to: Maria Luise Koening, Departamento de Oceanografia, Universidade Federal \\ de Pernambuco, Av. Arquitetura, s/n, Cidade Universitária, CEP 50670-901, \\ Recife, Pernambuco, Brazil, e-mail: koening@npd.ufpe.br \\ Received July 16, 2002 - Accepted Febreuary 17, 2003 - Distributed febrruary 29, 2004
}

(With 8 figures)

\begin{abstract}
The Botafogo estuary is of socio-economical importance for Pernambuco State. It is located at the north of Santa Cruz Channel, Itamaracá, Pernambuco, Brazil (07'42'50"S and 34 $\left.52^{\prime} 10^{\prime \prime} \mathrm{W}\right)$. There is a critical need to understand its functioning because of the rate at which this area is being converted to land uses. The phytoplankton dynamics was studied to enhance the knowledge of and verify the possible changes which have occurred in this ecosystem. Sampling was carried out with a plankton net 65 micrometers mesh size for qualitative data, and a Van Dorn bottle for quantitative data. Concurrent hydrological and chlorophyll- $a$ data were collected. Samplings were made in one fixed station in July 1996 (rainy season) and December 1996 (dry season), at 3-hour intervals during 24 hours. Eighty-seven specific and infra-specific taxa were identified from net plankton samples. Diatoms were most frequent, mainly Coscinodiscus centralis and Odontella regia in the rainy and dry seasons, respectively. Phytoplankton density varied from 205,000 to $1,210,000$ cell. $\mathrm{L}^{-1}$ in the dry season, and from 230,000 to $2,510,000$ cell. $\mathrm{L}^{-1}$ in the rainy season, indicating eutrophic conditions. Most numerically abundant were the diatoms Cyclotella meneghiniana and Cylindrotheca closterium and the phytoflagellates. The ecosystem is polluted, and deleterious effects are minimized by the marine influence which allows periodic water renewal.
\end{abstract}

Key words: estuarine phytoplankton, nyctemeral variation, tropical.

\section{RESUMO}

\section{Variação nictemeral do fitoplâncton em um estuário tropical (Itamaracá, Pernambuco, Brasil)}

O estuário do rio Botafogo tem grande importância socioeconômica para o Estado de Pernambuco. Esse estuário está localizado ao norte do Canal de Santa Cruz, em Itamaracá, Pernambuco, Brasil (07² $42^{\prime} 50^{\text {”'S }}$ e 34 $\left.52^{\prime} 10^{\prime \prime} \mathrm{W}\right)$. Há uma necessidade crítica de entender seu funcionamento em razão de a área ser convertida em outros usos. A dinâmica do fitoplâncton foi estudada para aumentar o conhecimento sobre o grupo e verificar as possíveis mudanças ocorridas no ecossistema. Para o estudo qualitativo foram realizadas amostragens com uma rede de plâncton com abertura de malha de 65 micrômetros e, para o quantitativo, utilizou-se uma garrafa de Van Dorn. Paralelamente foram coletados dados de hidrologia e clorofila- $a$. As amostragens foram feitas em uma estação fixa em julho/1996 (período chuvoso) e dezembro de 1996 (período seco), em intervalos de 3 horas, durante 24 horas. Foram identificados 87 táxons específicos e infra-específicos no plâncton de rede. As diatomáceas foram as mais frequentes, principalmente Coscinodiscus centralis e Odontella regia, respectivamente, nos períodos chuvoso e seco. A densidade fitoplanctônica variou de 205.000 a 1.200 .000 céls. $\mathrm{L}^{-1}$ no período seco, e de 230.000 a 2.510 .000 céls. $\mathrm{L}^{-1}$ no chuvoso, indicando condições eutróficas. A maior abundância numérica foi das diatomáceas Cyclotella 
meneghiniana e Cylindrotheca closterium e dos fitoflagelados. O ecossistema é poluído e os efeitos negativos são minimizados pela influência marinha, permitindo renovação periódica.

Palavras-chave: fitoplâncton, estuário, variação nictemeral, tropical.

\section{INTRODUCTION}

Estuaries are among the most important ecosystems due to their high productivity (Diegues, 1987). However, they have been subjected to domestic and industrial effluents contamination that, under extreme conditions, can affect their productivity (Day-Júnior et al., 1989). In these ecosystems, the phytoplankton community is the main primary producer, contributing to fertility, the herbivores, and the other animals of the next trophic levels who are directly dependent on them (Tait, 1970). Thus, knowledge of this community is fundamental for characterizing ecologically estuaries.

The Itamaracá mangrove estuarine system is located at $7^{\circ} 34^{\prime} 00^{\prime \prime}-77^{\circ} 55^{\prime} 16^{\prime \prime} \mathrm{S}$ and $34^{\circ} 48^{\prime} 48^{\prime \prime}$ $34^{\circ} 52^{\prime} 24^{\prime \prime} \mathrm{W}$, about $50 \mathrm{~km}$ north of Recife, Pernambuco State. It consists of the u-shaped Santa Cruz Channel, which is $20 \mathrm{~km}$ in length, as well as two connections to the South Atlantic Ocean, and five tributaries draining into the channel: Catuama, Carrapicho, Botafogo, and Congo, in the north portion, and Igarassu in the south. The system sustains $36 \mathrm{~km}^{2}$ of mangrove forests, dominated by Rhizophora mangle, Laguncularia racemosa, and Avicennia spp. (Medeiros \& Kjerfve, 1993).

This ecosystem is of socio-economical importance for Pernambuco State, and a critical need exists to understand its functioning because of the rate at which the areas which it includes are being converted to land uses (Neumann-Leitão et al., 2001).

Among the tributaries draining into the channel, the Botafogo River is the most polluted, presenting visible signs of degradation due to industrial effluents (CPRH, 1977; Barros-Franca, 1980; Eskinazi-Leça et al., 1984; Passavante \& Koening, 1984; CPRH, 1999). Along its course, there are four polluting industries, and many cities along its basin which have no treatment facilities, complicate the situation by disposal of their raw sewage in the river. Due to this critical pollution condition and the threat it presents to the Itamaracá system, a monitoring program is urgently needed. Thus, the objective of the present investigation is to study the diel variation of the phytoplankton community and its relation with some hydrological parameters during the rainy and the dry seasons, in order to contribute to existing knowledge and verify the possible changes occurring in this ecosystem.

\section{MATERIAL AND METHODS}

With a $280 \mathrm{~km}^{2}$ basin, the Botafogo River is located along side the city of Itapissuma ( $07^{\circ} 42^{\prime} 50^{\prime \prime}$ S and $\left.34^{\circ} 52^{\prime} 10^{\prime \prime} \mathrm{W}\right)$. The climate is warm-humid, pseudo-tropical with a mean annual temperature of $24^{\circ} \mathrm{C}$ and rainfall of $1500-2000 \mathrm{~mm} \cdot \mathrm{yr}^{-1}$, concentrated from March to August. Humidity is higher than $80 \%$. Predominant winds are from the southeast.

The samples for the present study were collected in one fixed station (Fig. 1) located at the Botafogo River, in the rainy and dry seasons (July and December 96), in spring tides, at three-hour intervals during a 24-hour period, corresponding to two consecutive tidal cycles (high, flood, low, and ebb tides).

Hydrological data were collected at the surface with a Nansen bottle: water temperature, reversion thermometer affixed to Nansen bottle; salinity, MohrKnudsen method and dissolved oxygen, Winkler method (Strickland \& Parsons, 1972). Saturation was calculated by The International Oceanographic Tables (UNESCO, 1973), and $\mathrm{pH}$ by Beckman Zeromatic II pHmeter. Data on nutrients (nitrite, nitrate, phosphate, silicate) followed the techniques described by Strickland \& Parsons (1972) and Grasshoff et al. (1983).

Samples for determination of chlorophyll- $a$ were collected with a 1-liter Van Dorn bottle at the surface. These were measured spectrophotometrically according to Parsons \& Strickland (1963).

Phytoplankton was collected with a Van Dorn bottle and preserved in Lugol's solution. The Utermöhl method (Edler, 1979) was used to quantify and identify taxa under a WILD M-40 inverted microscope based on the transect method, with an amplification of $450 \mathrm{x}$ (Vollenweider et al., 1974). Organisms were stained with Bengal Rose for better visualization. The phytoflagellates were identified to group level. 


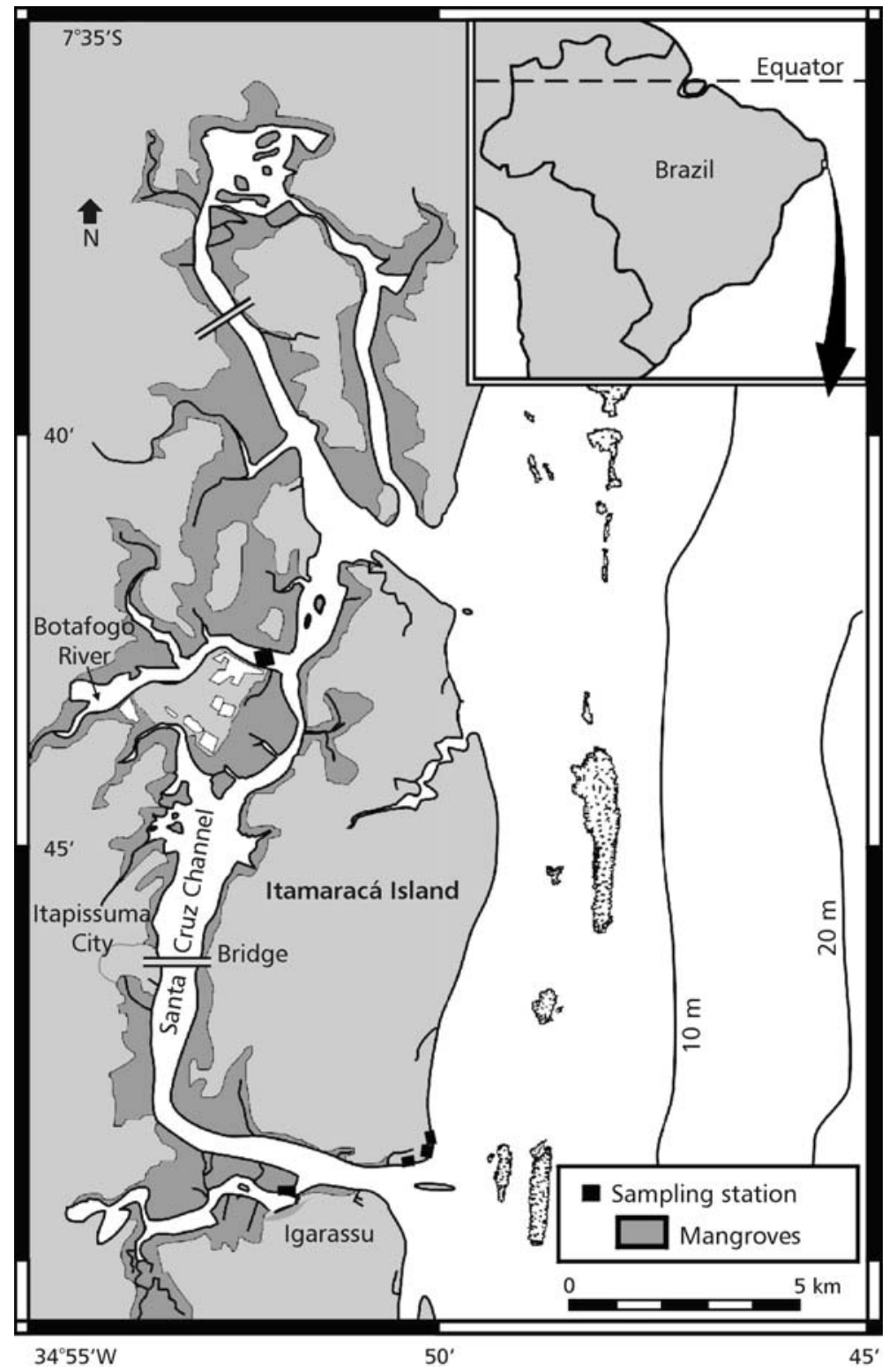

Fig. 1 - Itamaracá estuarine ecosystem and Botafogo River sampling station (Pernambuco, Brazil).

For qualitative studies, phytoplankton was collected with a standard plankton net $65 \mu \mathrm{m}$ mesh size hauled to the surface for three minutes. A flowmeter was fitted onto the opening of the net used. Samples were preserved in a $4 \%$ buffered formalin/seawater solution. The floristic composition was based on identification of the specific and infra-specific taxa. For this analysis, sub- samples of $0.5 \mathrm{ml}$ were observed under a Bausch $\&$ Lomb binocular microscope. Permanent slides were made for confirmation of diatom species (Muller-Melchers \& Ferrando, 1956). Microalgae identification and diatom nomenclature followed (Desikachary, 1959; Prescott, 1975; Tomas, 1997; Hasle, 1983; Lange et al., 1992; Round et al., 1990). 
Species diversity was based on Shannon (1948), and evenness on Pielou (1977).

Samples cluster analysis and principal component analysis were based on a matrix of phytoplankton density (cells. $\mathrm{L}^{-1}$ ) and environmental parameters using the Pearson moment-product correlation coefficient. Taxa with less than $25 \%$ of frequency of occurrence were excluded from this analysis as their results had no ecological meaning. The NTSYS (Numerical Taxonomy and Multivariate Analysis System) program from Metagraphics Software Corporation, California, USA (Leps et al., 1990) was used.

\section{RESULTS}

\section{Hydrology}

A salinity gradient of $16.86 \%$ existed in surface water between dry and rainy seasons, demonstrating a well-defined seasonal variation, with the highest values being registered during the dry season: $33.69 \% 0(4 \mathrm{pm})$ and $34.22 \%$ (4 am) at high tide. The lowest ones occurred during the rainy season: $17.36 \%$ (1 am) and $21.80 \%$ (1 pm) during flood tide.

The dissolved oxygen concentration varied from $3.09 \mathrm{ml}^{-1}(10 \mathrm{am})$ at low tide, to $4.26 \mathrm{ml}^{-1}(7$ am) at ebb tide, during the rainy season, corresponding to a saturation percentage of $62.80 \%$ to $89 \%$. During the dry season, the values oscillated between $2.56 \mathrm{ml}^{-1}(10 \mathrm{pm})$ at low tide, and 5.10 $\mathrm{ml}^{-1}(4 \mathrm{pm})$ at high tide, with saturation of 57.01 to $117.78 \%$.

The $\mathrm{pH}$ varied from 7.92 to 8.35 during the rainy season (flood and ebb tides, respectively), and from 7.09 to 8.08 during the dry season (flood and low tides, respectively) (Fig. 2).

The nitrite concentrations oscillated between 0.080 and $0.603 \mu$ g.at. $\mathrm{L}^{-1}$ during the rainy season, and 0.001 and $0.103 \mu \mathrm{g} . a t \cdot \mathrm{L}^{-1}$ during the dry season. The highest values were observed during the rainy season both in the high and ebb tides. The nitrate concentrations varied from 0.111 to $2.127 \mu$ g.at. $\mathrm{L}^{-1}$ during the rainy season, and 0.58 to $2.077 \mu$ g.at. $\mathrm{L}^{-1}$ during the dry season. The highest nitrate values were registered during the rainy season in the flood tides, and during the dry season in the ebb tide. The phosphate varied between 0.252 and 0.566 $\mu$ g.at. $\mathrm{L}^{-1}$ during the rainy season, and 0.194 and $0.478 \mu$ g.at. $\mathrm{L}^{-1}$ during the dry season. The highest values were observed during the rainy season in the low and flood tides. The silicate varied from 14.795 to $35.826 \mu$ g.at. $\mathrm{L}^{-1}$ during the rainy season, and 7.834 to $40.675 \mu$ g.at. $\mathrm{L}^{-1}$ during the dry season. The highest and the lowest values were registered during the dry season in the ebb and low tides, and the high tides, respectively (Fig. 3).

\section{Microphytoplankton composition}

A total of 87 species were identified, belonging to Cyanophyta (03), Pyrrophyta (06), Chrysophyta (77), and Chlorophyta (01), corresponding to $3.4 \%, 7.0 \%, 88.5 \%$, and $1.1 \%$ respectively (Table 1). Fifty-three species occurred in the rainy season and 62 during the dry season. During the rainy season, the most abundant species was Coscinodiscus centralis with percentages oscillating between $74 \%$ and $96 \%$. During the dry season, Odontella regia dominated with percentages varying from $31 \%$ to $98 \%$. The highest percentages of these species were from $10 \mathrm{pm}$ to $1 \mathrm{am}$, at low and flood tides (Fig. 4).

Coscinodiscus centralis and Pleurosigma/ Gyrosigma sp. occurred in all samples (100\%). Actinoptychus splendens, Bellerochea malleus, Cerataulus turgidus, Entomoneis alata, Gyrosigma balticum, Nitzschia sigma, Odontella regia, Pennatae Diatom, Petrodictyon gemma, Protoperidinium sp., and Surirella febigerii $(>70 \%)$, were very frequent, comprising a very characteristic group in Brazil's Northeast estuaries. Species presenting percentages ranging from $50 \%$ to $69 \%$ were frequent, such as Campylodiscus clypeus, Chaetoceros lorenzianus, Oscillatoria sp., Paralia sulcata, and Triceratium favus. The other species had low frequency (20 species) or were sporadic (48 species).

\section{Chlorophyll-a}

The chlorophyll- $a$ concentrations varied from 4.31 to $12.02 \mathrm{mg} \cdot \mathrm{m}^{-3}$ during the rainy season, and 0.15 to $8.72 \mathrm{mg} . \mathrm{m}^{-3}$ during the dry season (Fig. 5).

\section{Phytoplankton density}

The total density varied from 225,000 (1 am) to $2,510,000$ cells. $\mathrm{L}^{-1}(1 \mathrm{pm})$ during the rainy season and flood tide. During the dry season, the values oscillated between 230,000 ( 1 and $4 \mathrm{am}$ ) in the flood and high tide, and 1,210,000 cells. $\mathrm{L}^{-1}$ $(7 \mathrm{pm})$ in the ebb tide. Phytoplankton blooms were observed during the rainy season mainly at $13 \mathrm{pm}$ (flood tide). 

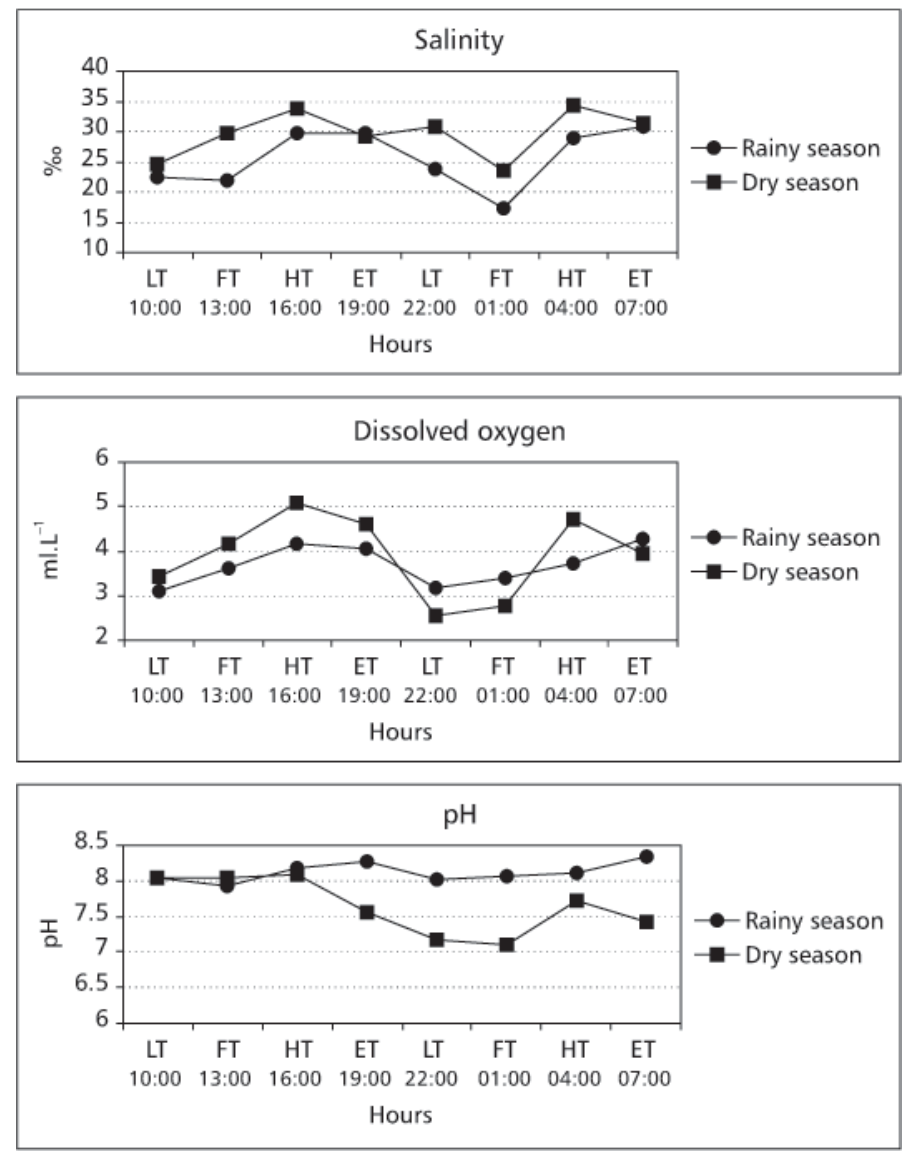

Fig. 2 - Nyctemeral variation of salinity, dissolved oxygen, and pH in Botafogo River estuary.

In the rainy season the diatoms dominated $\left(1,365,000\right.$ cells. $\left.\mathrm{L}^{-1}\right)$, and Cyclotella meneghiniana $\left(275,000\right.$ cells. $\left.\mathrm{L}^{-1}\right)$ and Cylindrotheca closterium $\left(920,000\right.$ cells. $\left.L^{-1}\right)$ followed by the phytoflagellates $\left(1,125,000\right.$ cells. $\left.L^{-1}\right)$. In the dry season phytoflagellates predominated $\left(1,040,000\right.$ cells. $\left.\mathrm{L}^{-1}\right)$ at $7 \mathrm{am}$ in the ebb tide, followed by the diatoms $\left(530,000\right.$ cells. $\left.\mathrm{L}^{-1}\right)$ at $10 \mathrm{am}$, outranking Cyclotella meneghiniana $\left(355,000\right.$ cells. $\left.\mathrm{L}^{-1}\right)$ (Fig. 6).

\section{Species diversity and evenness}

Low values were registered varying from 1 to 2 bits.cell. $\mathrm{L}^{-1}$ in both seasons. During the rainy season, diversity varied from $1.33(7 \mathrm{pm})$ to 2.81 bits.cell. $\mathrm{L}^{-1}(10 \mathrm{am})$ due to diatom predominance. During the dry season, diversity oscillated between 0.44 (7 am) and 2.29 bits.cell. $\mathrm{L}^{-1}(4 \mathrm{am})$ owing to phytoflagellate predominance. Evenness analysis presented generally medium values $(\sim 0.5)$. In the rainy season, the values varied from $0.44(7 \mathrm{pm})$ to $0.70(10 \mathrm{am})$; during the dry season, values oscillated between 0.15 (7 am) and $0.76(4 \mathrm{am})$ showing a uniform taxa distribution (Fig. 7).

\section{Samples association}

The cophenetic analysis revealed a good fit, showing four groups (Fig. 8). Group 1 was composed by the low and flood tides of the rainy season; group 2 clustered the low and ebb tides of the dry season; group 3 clustered all high tides from both rainy and dry seasons; group 4 associated the ebb tide of the rainy season. The main differences were observed between tides and seasons, although no seasonal differences were observed during high tide, when marine influence is very strong. 

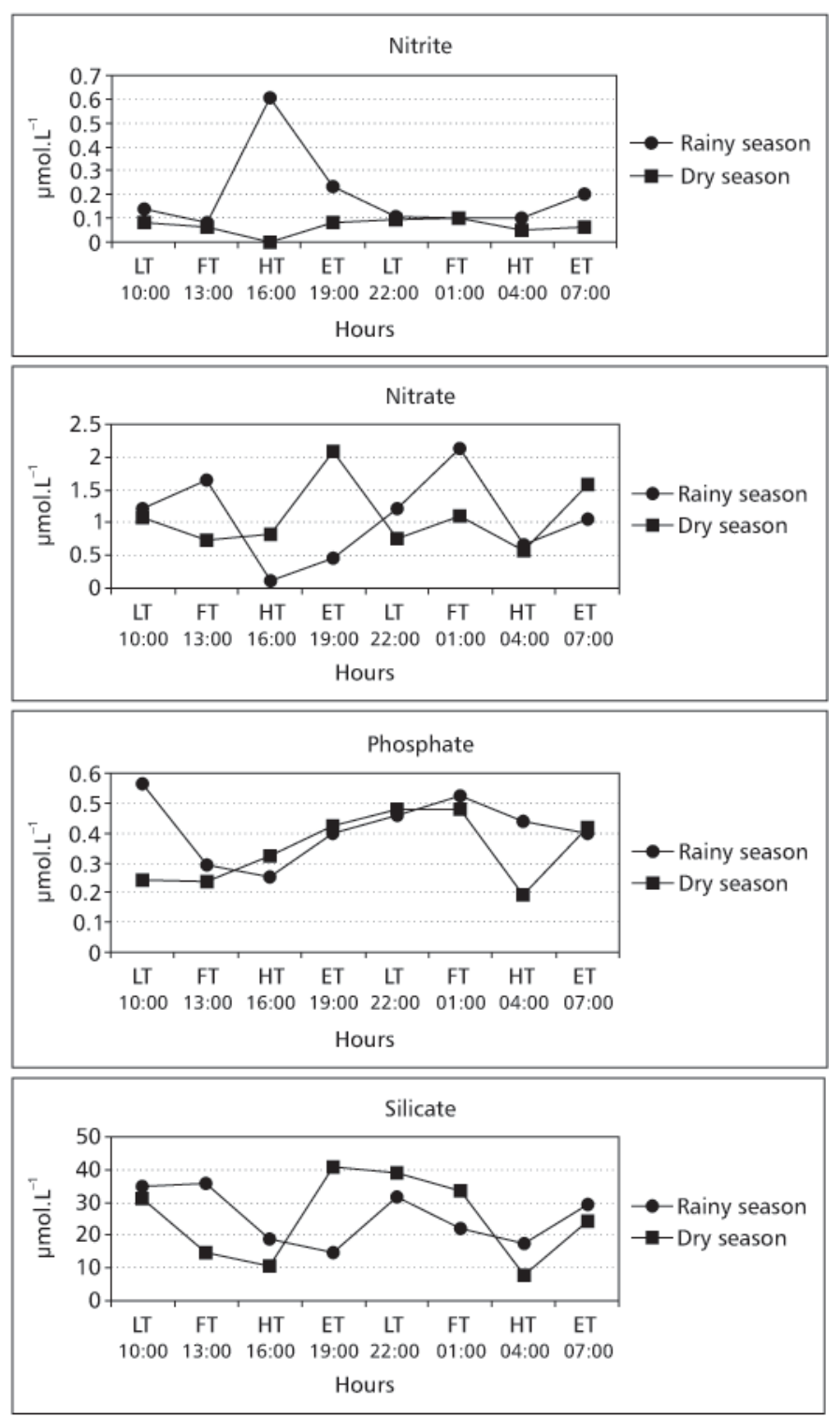

Fig. 3 - Nyctemeral variation of nutrient salts in Botafogo River estuary.

\section{Principal component analysis}

The first three components explained $71.61 \%$ of the data variation (Table 2). Factor 1 explained $31.81 \%$ of the total variation, and directly correlated Coscinodiscus centralis with Cylindrotheca closterium, pennatae diatom, silicate- $\mathrm{SiO}_{2}$, chlorophyll- $a$, phosphate- $\mathrm{PO}_{4}$, and specific diversity. These were inversely correlated to Rhizosolenia setigera, salinity, and dissolved and saturated oxygen. Factor 2 explained $23.29 \%$ of the data variation and directly correlated Gyrosigma balticum to Navicula sp. which were inversely correlated to Euglena acus. Factor 3 explained $16.51 \%$ of the data variation and correlated directly the phytoflagellates: Amphora arenaria, Chaetoceros danicus, and Nitzschia granulata, which were inversely correlated to evenness.

\section{DISCUSSION}

The Botafogo River estuary salinity data allows it to be classified as a euhaline to mesohaline regime. 
TABLE 1

Microphytoplankton floristic composition at Botafogo River estuary (Itamaracá, Pernambuco, Brazil) during July 1996 (rainy season) and December 1996 (dry season).

\begin{tabular}{|c|c|}
\hline DIVISION: CYANOPHYTA & Chaetoceros sp. \\
\hline CLASS: CYANOPHYCEAE & FAMILY: BIDDULPHIACEAE \\
\hline ORDER: NOSTOCALES & Biddulphia biddulphiana Smith \\
\hline FAMILY: OSCILLATORIACEAE & Biddulphia tridens Ehrenberg \\
\hline Lyngbya sp. & Bellerochea malleus (Bright.) Van Heurck \\
\hline Oscillatoria sp. & Cerataulina pelagica (Cleve) Hendey \\
\hline Planktothrix planctonica Elenkin & Cerataulina sp. \\
\hline DIVISION: PYRROPHYTA & Cerataulus smithii Ralfs \\
\hline CLASS: DYNOPHYCEAE & Cerataulus turgidus Ehrenberg \\
\hline ORDER: PERIDINALES & Ditylum brightwellii (West.) Grunow \\
\hline Ceratium candelabrum (Ehrenberg) Stein & Hydrosera sp. \\
\hline Ceratium furca (Ehrenberg) Claparède \& Lachmann & Isthmia enervis Ehrenberg \\
\hline Ceratium massiliense (Gourret) Jorgensen & Lithodesmium undulatum Ehrenberg \\
\hline Ceratium tripos tripos Balech & Odontella aurita (Lyngbye) Agardh \\
\hline Ceratium sp. & Odontella longicruris Greville Holan \\
\hline Protoperidinium sp. & Odontella mobiliensis (Bailey) Grunow \\
\hline DIVISION: CHRYSOPHYTA & Odontella regia (Shultz) Hendey \\
\hline CLASS: BACILLARIOPHYCEAE & Pleurosira laevis (Ehrenberg) Campère \\
\hline SUB-CLASS: CENTRICAE & Triceratium antediluvianum (Ehrenberg) Grunow \\
\hline FAMILY: COSCINODISCACEAE & Triceratium brockeii Leuduger-Fortmorel \\
\hline Coscinodiscus centralis Ehrenberg & Triceratium contortum Shadbolt \\
\hline Coscinodiscus sp. & Triceratium favus Ehrenberg \\
\hline Cyclotella meneghiniana Kützing & Triceratium parallelum Greville \\
\hline Melosira moniliformis (Müller) Agard & Triceratium pentacrinus (Ehrenberg) Wall. \\
\hline Melosira sp. & Triceratium pentacrinus var. quadrata Peragallo \\
\hline Paralia sulcata (Ehrenberg) Cleve & FAMILY: ANAULACEAE \\
\hline Thalassiosira leptopus (Grunow) Hasle \& Fryxell & Terpsinoe musica Ehrenberg \\
\hline FAMILY: ACTINODISCACEAE & SUB-CLASS: PENNATAE \\
\hline Actinoptychus splendens (Shadbolt) Ralfs & ORDER: ARAPHIDALES \\
\hline Actinoptychus senarius (Ehrenberg) Ehrenberg & FAMILY: FRAGILARIACEAE \\
\hline FAMILY: EUPODISCACEAE & Asterionellopsis glacialis (Catascrane) Round \\
\hline Auliscus caelatus Bailey & Climacosphenia moniligera Ehrenberg \\
\hline ORDER: SOLENIALES & $\begin{array}{l}\text { Pseudostaurosira brevistriata (Grunow) } \\
\text { Williams \& Round }\end{array}$ \\
\hline FAMILY: SOLENIACEAE & Fragilaria capucina Desmazières \& Kutzing \\
\hline Pseudosolenia calcaravis (Schultz) Sundstrom & Fragilaria sp. \\
\hline Rhizosolenia setigera Brightwell & Grammatophora marina (Lyng.) Kutz. \\
\hline Rhizosolenia sp. & Grammatophora oceanica (Ehrenberg) Grunow \\
\hline ORDER: BIDDULPHIALES & Grammatophora oceanica var. macilenta Smith \\
\hline FAMILY: CHAETOCERACEAE & Grammatophora sp. \\
\hline Chaetoceros affinis Lauder & Rhabdonema adriaticum Kutzing \\
\hline Chaetoceros lorenzianus Grunow & Synedra sp. \\
\hline
\end{tabular}


TABLE 1 (Continued.)

\begin{tabular}{|c|c|}
\hline ORDER: MONORAPHIDALES & FAMILY: NITZSCHIACEAE \\
\hline FAMILY: ACHNANTHACEAE & Bacillaria paxillifera Gmelin \\
\hline Cocconeis scutellum Ehrenberg & Cylindrotheca closterium Ehrenberg \\
\hline ORDER: BIRAPHIDALES & Nitzschia littoralis Grunow \\
\hline FAMILY: NAVICULACEAE & Nitzschia longissima (Breb.) Grunow \\
\hline Caloneis sp. & Nitzschia sigma (Kutzing) Smith \\
\hline Diploneis sp. & Nitzschia sp. \\
\hline Frustulia rhomboides (Ehrenberg) De Toni & FAMILY: SURIRELLACEAE \\
\hline Gyrosigma balticum (Ehrenberg) Cleve & Campylodiscus clypeus Ehrenberg \\
\hline Gyrosigma sp. & Campylodiscus sp. \\
\hline Pleurosigma/Gyrosigma sp. & Surirella fastuosa Ehrenberg \\
\hline Mastogloia splendida (Greville) Cleve & Surirella febigerri Lewis \\
\hline Petroneis humerosa (Breb.) Stick \& Mann & Petrodictyon gemma (Ehrenberg) Mann \\
\hline Navicula humerosa var. constricta Cleve & Surirella sp. \\
\hline Lyrella lyra (Ehrenberg) Karajeva & DIVISION: CHLOROPHYTA \\
\hline Navicula sp. & CLASS: CHLOROPHYCEAE \\
\hline FAMILY: CYMBELLACEAE & ORDER: ZIGNEMATALES \\
\hline Amphora sp. & FAMILY: DESMIDIACEAE \\
\hline FAMILY: AMPHIPRORACEAE & Staurastrum sp. \\
\hline Entomoneis alata (Ehrenberg) Kützing & \\
\hline
\end{tabular}

Overall salinity was lower in the rainy (average $25.51 \%$ ) than in the dry season $(29.61 \%$ ). This salinity pattern conditioned the dominant phytoplankton group by season. For example, diatoms and phytoflagellates were about equally important, although the former dominated in the rainy season and the latter was more significant during the dry season. This phytoplankton seasonal trend appears to be common in many estuaries of the region, including of the Paripe River (Lacerda et al., 1998), Santa Cruz Channel (Eskinazi-Leça et al., 2000), and Ponta do Seixas, PB, a few kilometers north of the studied area (Sassi et al., 1991).

The same pattern, or the predominance of phytoflagellates followed by diatoms during the rainy season, was observed in Cananéia, SP (Brandini, 1982). This may reflect changing conditions of transparence, nutrient availability, and different abilities of various species to exploit changing conditions. Summer species (phytoflagellates) have higher light optima, shorter generation times, and are motile (Smayda, 1980). Diatoms, which dominate in well-mixed areas, are replaced by phytoflagellates in the shallow quiescent waters influenced by input from surrounding mangrove and seagrass communities.

Total phytoplankton density was higher in the rainy season, and among the diatoms the most common were Cyclotella meneghiniana and Cylindrotheca closterium, both littoral species according to SilvaCunha (2001). These species were followed in numerical abundance by phytoflagellates. During the dry season, the density was lower and phytoflagellates were the most abundant, followed by diatoms.

Besides the above mentioned diatoms, Coscinodiscus centralis and Odontella regia dominated among the net plankton in both seasons. Both species are marine planktonic, characterize the net phytoplankton community of the Santa Cruz Channel, and are considered indicators in Brazilian estuaries (Barros-Franca et al., 1981; Eskinazi-Leça et al., 1984, 2000; Lacerda, 1994; Lacerda et al., 1998). In principal component analysis, Coscinodiscus centralis correlated directly with silicate, phosphate, and chlrorophyll- $a$, showing its affinity with euthrophic conditions. 



Fig. 4 - Main relative abundance of the microphytoplankton groups at Botafogo River estuary during 24 hours in July 1996 (rainy season) and December 1996 (dry season).

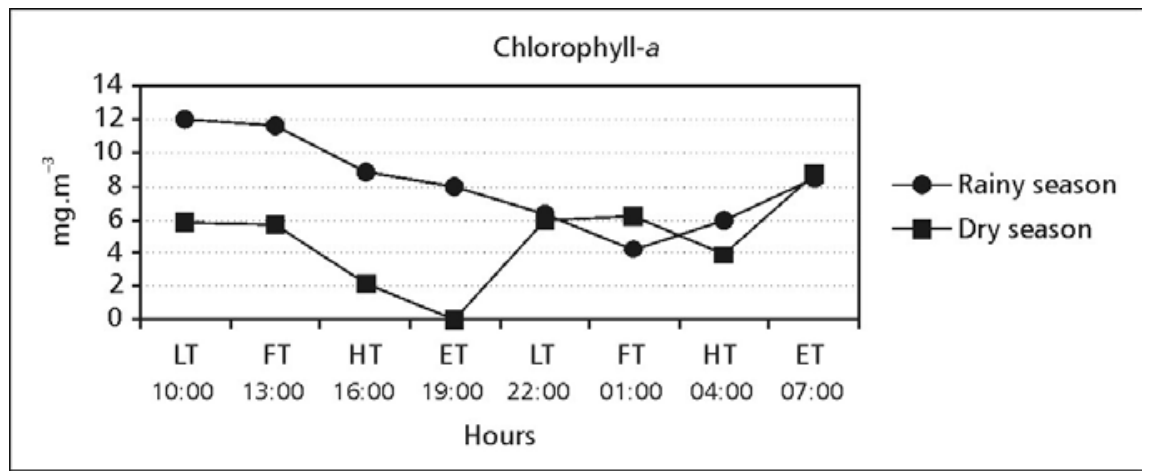

Fig. 5 - Nyctemeral variation of chlorophyll- $a$ in Botafogo River estuary. 
In the Botafogo estuary, as far as nutrient average values, no difference was registered during the two seasons, except for nitrite which was much higher during the rainy season. Although no great difference was observed between seasons, it is supposed that there was a higher quantity of nutrients in the rainy season, and that they were consumed by the phytoplankton.

The nutrients referred to come from continental flux and fertilizers drained during the rainy season from the sugarcane agro-industry. Nutrient removal from the sediment was also registered during the rainy season, when water turbulence was intensified by winds and tides (Eskinazi-Leça et al., 1997). Thus, the nutrient concentrations were influenced by land drainage and bottom sediments, with higher values of nitrogen-containing compounds observed during the rainy season, which contributed to the higher phytoplankton densities at that time. On the other hand, Flores-Montes et al. (2002) mention that nitrogen was supposedly a limiting factor, at Santa Cruz Channel where the Botofogo River discharges.

This maximum phytoplankton density in the rainy season was followed by an increase in chlorophyll- $a\left(8.206 \mathrm{mg} \cdot \mathrm{m}^{-3}\right)$. A general pattern of highest production in the rainy season has been reported for other estuaries in Pernambuco State such as the Santa Cruz Channel (Passavante, 1981), Paripe River (Silva \& Koening, 1993), and Goiana, PE (Campelo et al., 1999). Although a clear seasonal cycle was observed, a nyctemeral cycle with highest values during the period of higher light intensity was observed only during the rainy season, suggesting that light is one of the limiting factors.
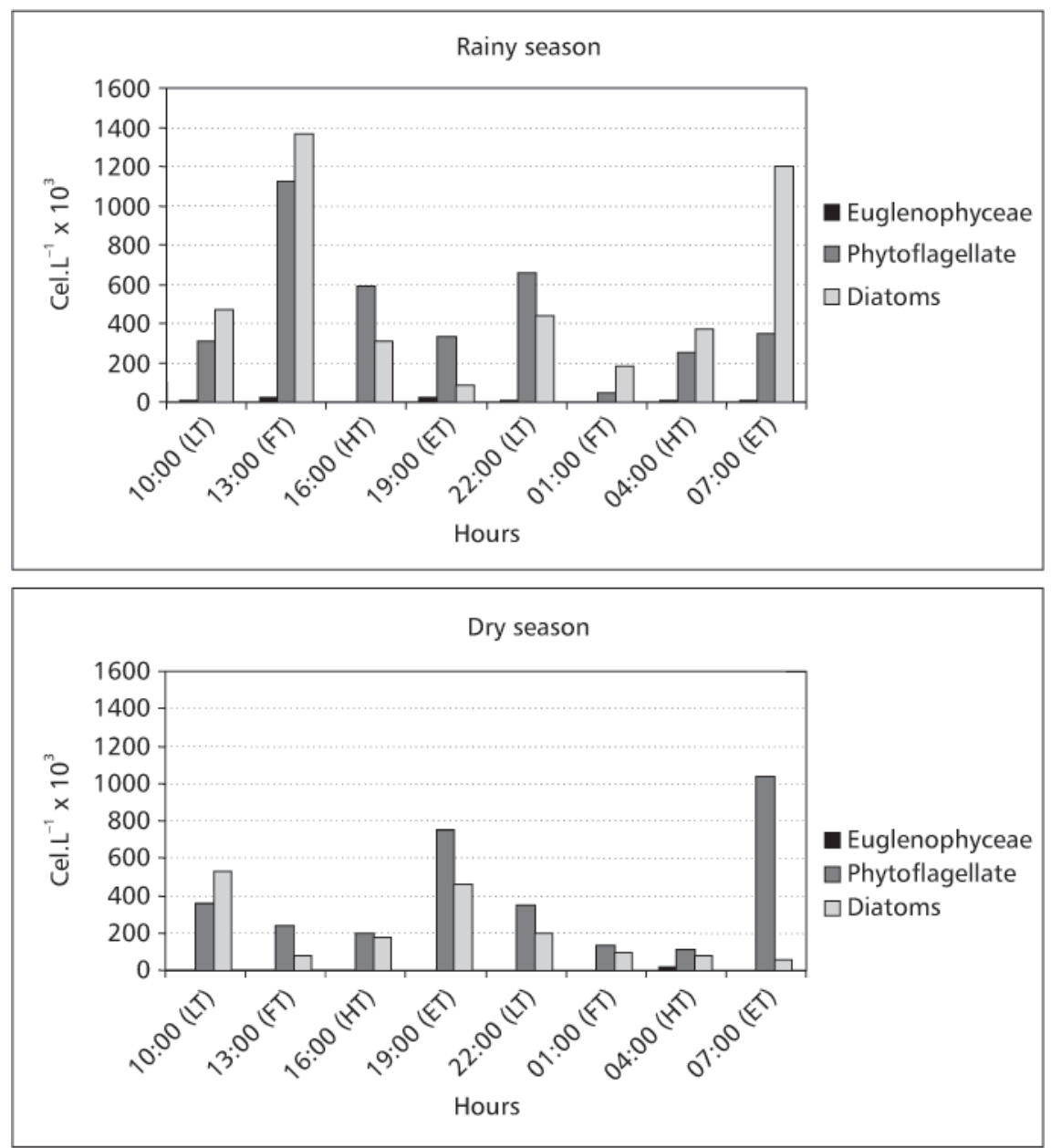

Fig. 6 - Quantitative variation of the studied groups in Botafogo River estuary during 24 hours in July 1996 (rainy season) and December 1996 (dry season). 

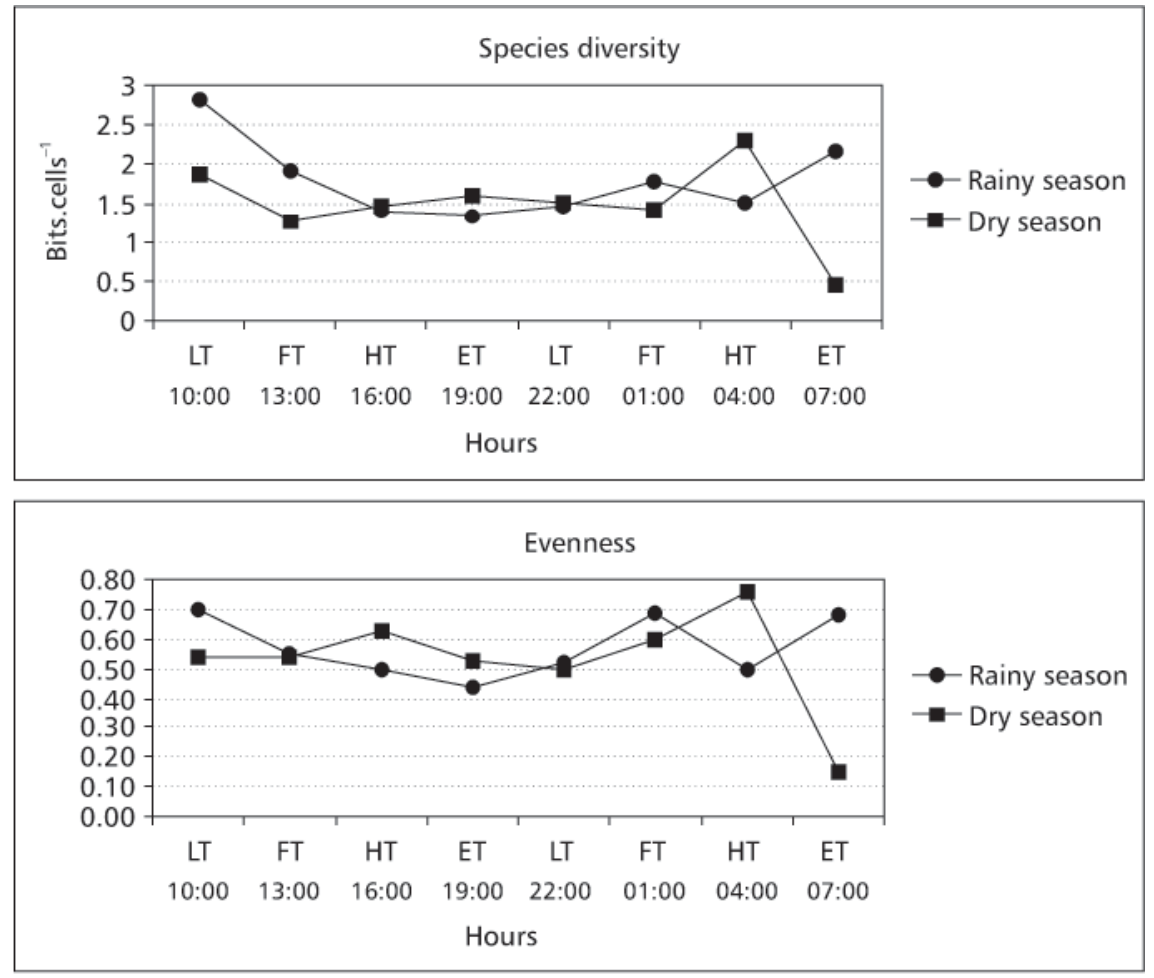

Fig. 7 - Phytoplankton diversity (bits.cells ${ }^{-1}$ ) and evenness taxa at Botafogo River estuary.

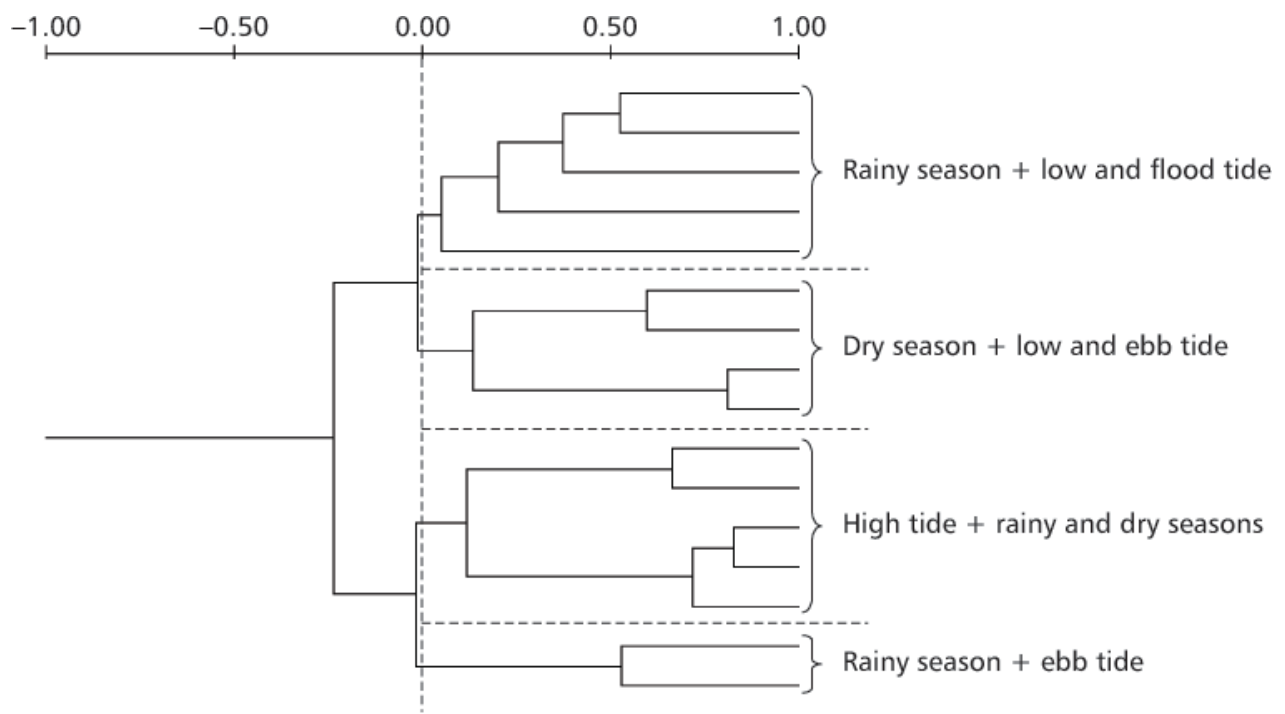

Fig. 8 - Dendrogram of the samples association at Botafogo River estuary. LT $=$ low tide; FT $=$ flood; HT $=$ high tide; ET = ebb tide; $\mathrm{R}=$ rainy season; $\mathrm{D}=$ dry season. 
TABLE 2

Principal component analysis of phytoplankton taxa and environmental parameters of Botafogo River estuary.

\begin{tabular}{|c|c|c|c|}
\hline Taxa and parameters & $\begin{array}{c}\text { Factor } 1 \\
31.81 \%\end{array}$ & $\begin{array}{c}\text { Factor } 2 \\
23.29 \%\end{array}$ & $\begin{array}{c}\text { Factor } 3 \\
16.51 \%\end{array}$ \\
\hline Euglena acus & -0.350 & -0.619 & 0.011 \\
\hline Fitoflagelados & 0.424 & -0.367 & 0.778 \\
\hline Amphora arenaria & 0.021 & 0.626 & 0.680 \\
\hline Chaetoceros danicus & 0.497 & -0.280 & 0.733 \\
\hline Coscinodiscus centralis & 0.861 & 0.448 & 0.060 \\
\hline Cyclotella meneghiniana & 0.445 & 0.403 & 0.292 \\
\hline Cylindrotheca closterium & 0.651 & -0.197 & 0.206 \\
\hline Diatomácea Pennatae & 0.853 & 0.533 & -0.253 \\
\hline Gyrosigma balticum & 0.098 & 1.000 & -0.107 \\
\hline Navicula sp. & 0.395 & 0.808 & 0.169 \\
\hline Nitzschia granulata & -0.115 & 0.569 & 0.736 \\
\hline Rhizosolenia setigera & -1.000 & 0.538 & -0.051 \\
\hline + Temperature & -0.557 & -0.188 & 0.306 \\
\hline Salinity & -0.687 & 0.359 & 0.319 \\
\hline Dissolved oxigen & -0.654 & 0.433 & 0.361 \\
\hline Oxygen saturation & -0.720 & 0.401 & 0.407 \\
\hline $\mathrm{pH}$ & -0.221 & 0.507 & -0.365 \\
\hline Nitrite & 0.077 & -0.199 & -0.245 \\
\hline Nitrate & 0.264 & 0.207 & 0.347 \\
\hline Phosphate & 0.608 & 0.125 & -0.149 \\
\hline Silicate & 0.784 & -0.126 & 0.263 \\
\hline Chlorophyll- $a$ & 0.741 & -0.123 & 0.242 \\
\hline Specific diversity & 0.606 & 0.332 & -0.484 \\
\hline Evenness & 0.102 & 0.597 & -0.623 \\
\hline
\end{tabular}

In estuaries, the high turbidity caused by greater continental discharge during the rainy season, associated with tidal turbulence should limit phytoplankton development. However, at this season the phytoplankton density was almost twice that of the dry season. Maybe this is a consequence of transparency increase due to the construction of a dam upstream to supply water to the population of Recife (Lira, 1975). Prior to the existence of this dam, the Botafogo River had an average flow of $4.460{\mathrm{~L} . \mathrm{s}^{-1}}^{-1}$ measured in July 1973, which is presently reduced to less than a third (FloresMontes et al., 2002). Besides this, industrial and urban effluent disposal seaward of the dam have been impacting the whole Botafogo system (Macêdo et al., 2000). In areas where land is of little influence and the amount of suspended material is not decreasing the euphotic zone, phytoplankton can show higher flowering during the rainy season since higher nutrient values prevail (Eskinazi-Leça et al., 1997). Phytoplankton production increase associated with the precipitation regime can also be verified in Brazilian estuaries, such as Ubatuba, Santa Cruz Channel, Cananéia, and the Paranaguá Bay (Kutner, 1972; Tundisi et al., 1973; Tundisi et al., 1978; Passavante, 1979; Brandini, 1985).

Although a high pollution load has been detected in the Botafogo river estuary, the values registered in this research show a normal dissolved oxygen saturation zone (average $81.61 \%$ ). This is probably due to the great influence of marine waters on this river estuary which results in water renewal (Macêdo et al., 1982). 
The dissolved oxygen correlates directly with salinity and with Rhizosolenia setigera, which is a marine planktonic oceanic species (Silva-Cunha, 2001), thus confirming the marine influence in this river.

Numerous factors regulate the magnitude, seasonal pattern, and species composition of phytoplankton photosynthesis, including light, temperature, nutrients, physical transport processes, and herbivory. As suggested by Boynton et al. (1982), these factors also affect phytoplankton assemblages on both the ecological scale and at the level of individual cells. On the ecological scale, environmental factors influence phytoplankton through species selection. In addition, adaptation to these changing environmental conditions is regulated on the physiological scale by intracellular biochemical mechanisms, including changes in enzymes and pigment concentrations in such a way as to provide a near-optimal response for specific species. The relative significance of these factors apparently varies from one system to the next.

The high density of diatoms and phytoflagellates leads to a low species diversity, a common fact in estuaries. The specific diversity in tropical seas is directly related to mechanisms that react to a continuous interaction between communities of different water bodies, and also between those limited by nutrients. When nutrients are available, higher development of small-sized species can occur, with high reproduction rates, increasing the density and decreasing the diversity. The low values of diversity registered in the studied estuary are an answer to the predominance of nanophytoplankton species. The sharply higher values of species diversity were due to the environmental heterogeneity, to which littoral species contributed with 33 taxa.

As with many estuaries, the Botafogo ecosystem is exposed to multiple pressures from industrial pollution, domestic sewage discharge, urban expansion, land reclamation, and fisheries. Thus, this estuary is considered a critical area in terms of pollution, but it seems that environmental impacts are minimized by continuous influence of marine waters across the Santa Cruz Channel north outlet, which constantly renews estuary waters.

\section{REFERENCES}

BARROS-FRANCA, L. M. de, 1980, Composição e aspectos ecológicos do fitoplâncton do rio Botafogo (PE). Dissertação de Mestrado, UFRPE, Recife, 118p.
BARROS-FRANCA, L. M. de, ESKINAZI-LEÇA, E. \& SILVA, M. G. G., 1981, Estudo ecológico da região de Itamaracá, Pernambuco-Brasil, XVI. Microfitoplâncton do estuário do rio Botafogo, 1981, pp. 297-220. In: Congresso Brasileiro de Engenharia de Pesca (ed.). Anais, SUDENE, Recife.

BRANDINI, F. P., 1982, Variação nictemeral de alguns fatores ecológicos na região de Cananéia (SP). Arquivos de Biologia e Tecnologia, 25: 313-327.

BRANDINI, F. P., 1985, Ecological studies in the bay of Paranaguá. Horizontal distribution and seasonal dynamics of the phytoplankton. Boletim do Instituto Oceanográfico da Universidade de São Paulo, 33: 139-147.

BOYNTON, W. R., KEMP, W. M. \& KEEFE, C. W., 1982, A comparative analysis of nutrients and other factors influencing estuarine phytoplankton production. In: Estuarine Comparisons. Academic Press, London, pp. 69-90.

CAMPELO, M. J. A., PASSAVANTE, J. Z. de O. \& KOENING, M. L., 1999, Biomassa fitoplanctônica (clorofila-a) e parâmetros ambientais na praia de Carne de Vaca, Goiana, Pernambuco, Brasil. Trab. Oceanog. Univ. Fed. PE, 27: 27-41.

COMPANHIA PERNAMBUCANA DE CONTROLE DE POLUIÇÃO AMBIENTAL E ADMINISTRAÇÃO DE RECURSOS HÍDRICOS (CPRH), 1977, Diagnóstico Preliminar das Condições Ambientais do Estado de Pernambuco. CPRH, Recife, 283p.

COMPANHIA PERNAMBUCANA DE CONTROLE DE POLUIÇÃO AMBIENTAL E ADMINISTRAÇÃO DE RECURSOS HÍDRICOS (CPRH), 1999, Relatório de Monitoramento de Bacias Hidrográficas do Estado de Pernambuco. CPRH, Recife, 184p.

DAY-JÚNIOR, J. W. et al., 1989, Estuarine ecology. J. Wiley, New York, 556p.

DESIKACHARY, T. V., 1959, Cyanophyta. Indian Council of Agricultural Researh, New Delhi, 686p.

DIEGUES, A. C., 1987, Conservação e desenvolvimento sustentado de ecossistemas litorâneos no Brasil, 1987, pp. 196-243. In: Simpósio sobre Ecossistemas da Costa Sul e Sudeste Brasileira: síntese dos conhecimentos. Anais, 3 v., ACIESP, São Paulo, 363p.

EDLER, L., 1979, Recommendations on methods for marine biological studies in the Baltic Sea: phytoplankton and chlorophyll. The Baltic Marine Biologists, 5: 1-38.

ESKINAZI-LEÇA, E., BARROS-FRANCA, L. M. \& MACÊDO, S. J. de, 1984, Estudos ecológicos da área de Itamaracá (Pernambuco, Brasil). XXV. "Standing Stock" do fitoplâncton do estuário do rio de Pernambuco. Trab. Oceanog. Univ. Fed. PE, 18: 153-192.

ESKINAZI-LEÇA, E., KOENING, M. L. \& SILVA-CUNHA, M. G. G., 2000, O fitoplâncton: estrutura e produtividade, pp. 67-74. In: H. M. Barros, E. Eskinazi-Leça, S. J. Macêdo \& T. Lima (eds.), Gerenciamento participativo de estuários e manguezais. Ed. Universitária da UFPE, Recife, 252p.

ESKINAZI-LEÇA, E., SILVA-CUNHA, M. G. G., KOENING, M. L., MACÊDO, S. J. de \& COSTA, K. M. P., 1997, Variação espacial e temporal do fitoplâncton na plataforma continental de Pernambuco-Brasil. Trab. Oceanog. da Univ. Fed. PE, 25: 1-16. 
FLORES-MONTES, M. de J., MACÊDO, S. J. de \& KOENING, M. L., 2002, N:Si:P Atomic ratio in the Santa Cruz channel, Itamaracá, PE (Northeast Brazil): a nyctemeral variation. Brazilian Archives of Biology and Tecnology, 2: 115-124.

GRASSHOFF, K., EHRHARDT, M. \& KREMLING, K., 1983 Methods of seawater analysis. Verlag Chemie, New York, 419p.

HASLE, G. R., 1983, The current status of the diatom genus Coscinodiscus Ehrenberg 1939. Bot. Mus. Rapp, 33: 27-32.

KUTNER, M. B. B., 1972, Variação estacional e distribuição do fitoplâncton na região de Cananéia. Tese de Doutorado, Instituto de Biociências da Universidade de São Paulo, São Paulo, 104p.

LACERDA, S. R., 1994, Variação diurna e sazonal do fitoplâncton no estuário do rio Paripe (Itamaracá, Pernambuco, Brasil). Dissertação de Mestrado, UFPE, Recife, 146p.

LACERDA, S. R., ESKINAZI-LEÇA, E. \& KOENING, M. L., 1998, Composição e variação da flora das diatomáceas no estuário do rio Paripe (Itamaracá, Pernambuco, Brasil). Trab. Oceanog. Univ. Fed. PE, 26: 19-30.

LANGE, C. B., HASLE, G. R. \& SYVERTSEN, E. E., 1992, Seasonal cycle of diatoms in the Skagerrak, North Atlantic, with emphasis on the period 1980-1990. Sarsia, 77: 173-187.

LEPS, J. et al., 1990, Annual cycles of plankton species composition and physical chemical conditions in Slapy Reservoir detected by multivariate statistics. Arch. Hydrobiol. Beih. Ergebn. Limnol., 33: 933-945.

LIRA, L., 1975, Geologia do canal de Santa Cruz e praia submarina adjacente à Ilha de Itamaracá, PE. Dissertação de Mestrado, UFRS, Porto Alegre, 107p.

MACÊDO, S. J. de, MELO, H. N. S. \& COSTA, K. M. P. da, 1982, Estudo ecológico da Região de Itamaracá, Pernambuco, Brasil. XXXIII. Condições hidrológicas do estuário do rio Botafogo. Trab. Oceanog. da Univ. Fed. PE, 17: 81-122.

MACÊDO, S. J. de, MONTES, M. de J. F. \& LINS, I. C., 2000 Características abióticas da área, pp. 7-25. In: H. M. Barros, E. Eskinazi-Leça, S. J. Macêdo \& T. Lima (eds.), Gerenciamento participativo de estuários e manguezais. Ed. Universitária da UFPE, Recife, $252 \mathrm{p}$.

MEDEIROS, C. \& KJERFVE, B., 1993, Hydrology of a tropical estuarine system: Itamaracá-Brasil. Estuarine, Coastal and Shelf Science, 36: 495-515.

MULLER-MELCHERS, F. C. \& FERRANDO, H. J., 1956, Técnicas para el estudio de las diatomaceas. Boletim do Instituto Oceanográfico, 7: 151-160.

NEUMANN-LEITÃO, S., SCHWAMBORN, R., MACÊDO, S. J., MEDEIROS, C., KOENING, M. L., MONTES, M J. F., FEITOSA, F. A. N. \& GUSMÃO, L. M. O., 2001, Plankton dynamics at Itamaracá mangrove estuarine system, Pernambuco, Brazil, pp.435-454. In: Y. Villacampa, C. A. Brebia \& J.-L. Usó (eds.), Ecosystems and sustainable development III. Wit Press, Boston.

PARSONS, T. R. \& STRICKLAND, J. D. H., 1963, Discusson of spectrophometric determination of marine-plant pigments, with revised equations for ascertaining chlorophyll- $a$ and carotenois. Journal Marine Research, 21: 105-156.

PASSAVANTE, J. Z. de O., 1979, Produção primária do fitoplâncton do canal de Santa Cruz (Itamaracá, Pernambuco). Tese de Doutorado, Instituto Oceanográfico, USP, São Paulo,188p.
PASSAVANTE, J. Z. de O., 1981, Estudo ecológico da região de Itamaracá, Pernambuco, Brasil. XXI. Biomassa do nano e microfitoplâncton do Canal de Santa Cruz. Trab. Oceanog. da Univ. Fed. PE, 16: 105-156.

PASSAVANTE, J. Z. de O. \& KOENING, M. L., 1984, Estudo ecológico da região de Itamaracá, Pernambuco. XXVI. Clorofila- $a$ e material em suspensão no estuário do rio Botafogo. Trab. Oceanog. da Univ. Fed. PE, 18: 207-230.

PIELOU, E. C., 1977, Mathematical ecology. Wiley, New York, $385 \mathrm{p}$.

PRESCOTT, G. W., 1975, Algae of the western great lakes area. Brown Company Publishers, Dubuque, 977p.

ROUND, F. E., CRAWFORD, R. M. \& MANN, D. G., 1990, The diatoms. Biology \& Morphology of the genera. Cambridge University Press, Cambridge, $747 \mathrm{p}$.

SASSI, R., VÊLOSO, T. M., MELO, G. N. \& MOURA, G. F. de, 1991, Variações diurnas do fitoplâncton e de parâmetros hidrológicos em recifes costeiros do Nordeste do Brasil, pp. 61-82. In: Encontro Brasileiro de Plâncton (ed.), Anais, 499p., UFPE, Recife.

SILVA, I. G. \& KOENING, M. L., 1993, Variação sazonal da densidade fitoplanctônica no estuário do rio Paripe, Itamaracá, Pernambuco, Brasil. Arq. Biol. Tecnol., 4: 645-658.

SILVA-CUNHA, M. G. G., 2001, Estrutura e dinâmica da flora planctônica no canal de Santa Cruz, Itamaracá, Nordeste do Brasil. Tese de Doutorado, UFPE, Recife, 170p.

SHANNON, C. E. A., 1948, Mathematical theory of communication. Bulletin of System Technology Journal, 27: 379-423.

SMAYDA, T. J., 1980, The phytoplankton species sucession, pp. 497-570. In: I. Morris (ed.), The physiological ecology of phytoplankton. University of California Press, Berkeley, 625p.

STRICKLAND, J. D. H. \& PARSONS, T. R., 1972, A pratical handbook of seawater analysis. Bulletin Fisheries Research Board of Canada, 167: 207-211.

TAIT, R. V., 1970, Elementos de Ecologia Marina. Ed. Acribia, Zaragoza, 302p.

TOMAS, C. R., 1997, Identifying marine phytopanckton. Academic Press, San Diego, 858p.

TUNDISI, J. G., TUNDISI, T. M. \& KUTNER, M. B. B., 1973, Plankton studies in a mangrove environment. VIII. Further investigations on primary production, standing stock of phyto and zooplankton and some environmental factors. International Revue der Gesamtem Hydrobiologie, 58: 925-940.

TUNDISI, J. G. et al., 1978, Plankton studies in a mangrove environment. IX. Comparative investigations with coastal oligotrophic waters. Rev. Brasil. Biol., 38: 301-320.

UNESCO, 1973, International oceanographic tables. Wormley, 2. v., $141 \mathrm{p}$.

VOLLENWEIDER, R. A., TALLING, J. I. \& WESTLAKA, D. F., 1974, A manual on methods for measuring primary production in aquatic environments. International biological Programe Handbook, London, 225p. 